\title{
Searching for Sophia in Music Production: A Comparative Study of the Swedish Music Industry's Impact on Future Higher Education in Music
}

\author{
Jan-Olof Gullö \\ Royal College of Music, Stockholm, Sweden \\ Hans Gardemar \\ Royal College of Music, Stockholm, Sweden
}

This paper was presented at the 2019 International Summit of the

Music \& Entertainment Industry Educators Association

March 21-23, 2019

$\underline{\text { https://doi.org/10.25101/19.22 }}$

\section{Abstract}

Although Sweden is a small country with just ten million inhabitants, Swedish music exports have been very successful for many years. The international success of companies like Spotify, Cheiron, and Maratone and individuals like Max Martin and Shellback has resulted in a growing interest among students in Sweden to study music and music production. Therefore, the aim of this study is to analyze the motives that exist among young people who choose to study music and to compare such motives with perceptions among leading music industry professionals. Firstly, we study various formal and informal learning processes relevant to music production and secondly, we focus on artistic aspects. A third aspect we study is technological development. But digitalization and online music distribution have not only led to new music production methods and business opportunities, it has also resulted in that established production traditions as well as the competencies among the professionals are challenged. The empirical data in this study consists of qualitative interviews with industry professionals and focus group interviews with students in higher education in music and music production. Learning theories as well as entrepreneurial theories were used to analyze the collected data. The results indicate some clear differences between what the students and the industry professionals value as important. One such difference is entrepreneurial skills, which are valued higher by the interviewed professionals. The results also indicate that many of the students who study music in higher education primarily aim at a career as artists, producers, or songwriters in popular music. This may be a potential problem as most of the music education offered not at all is focused on developing talents to full-fledged artists. The term Sophia [wisdom] refers to an- cient Greek knowledge typology and is used to summarize the theoretical framework of the project.

Keywords: music production, music production education, music education, Swedish music

Jan-Olof Gullö has a professional background as a musician, double bass/electric bass, record producer, and television producer. Although he was active in sports television production for many years in the $1990 \mathrm{~s}$, he has mainly worked with music and in recent years also as a researcher. He now holds the position as professor and academic research leader in music production at the

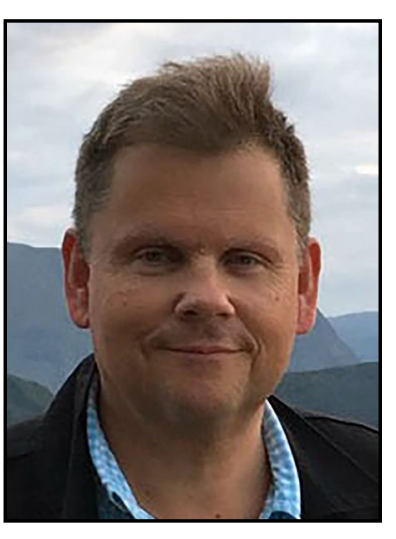
Royal College of Music in Stockholm, Sweden.

Hans Gardemar has a professional background as a musician, keyboard player, record producer/arranger, and bandleader. He has been professionally active in the music industry since the mid 80 s and has produced many artists in Scandinavia, and has, for example, been bandleader for more than twenty-five years for Björn Skiffs, who was a number one U.S. Billboard artist in the

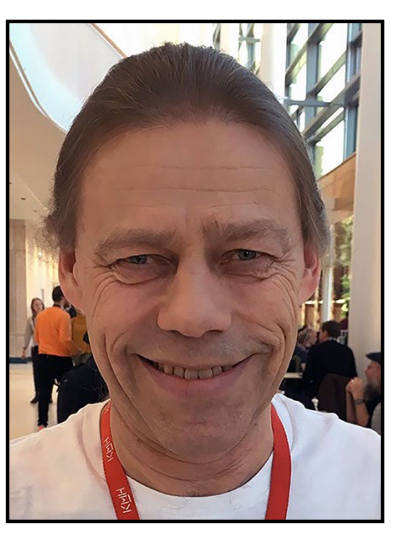
mid 70s. He has also recorded internationally and produced many artists, e.g., Scorpions, James Last, and many others. Since a few years back he also teaches music production at the Royal College of Music in Stockholm, Sweden. 


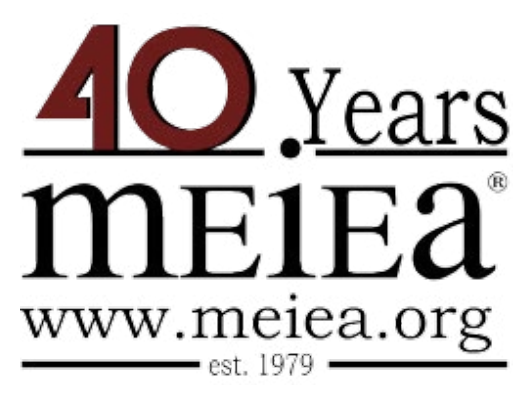

\section{PROCEEDINGS OF THE \\ 2019 INTERNATIONAL SUMMIT \\ OF THE \\ MUSIC \& ENTERTAINMENT \\ INDUSTRY EDUCATORS \\ ASSOCIATION}

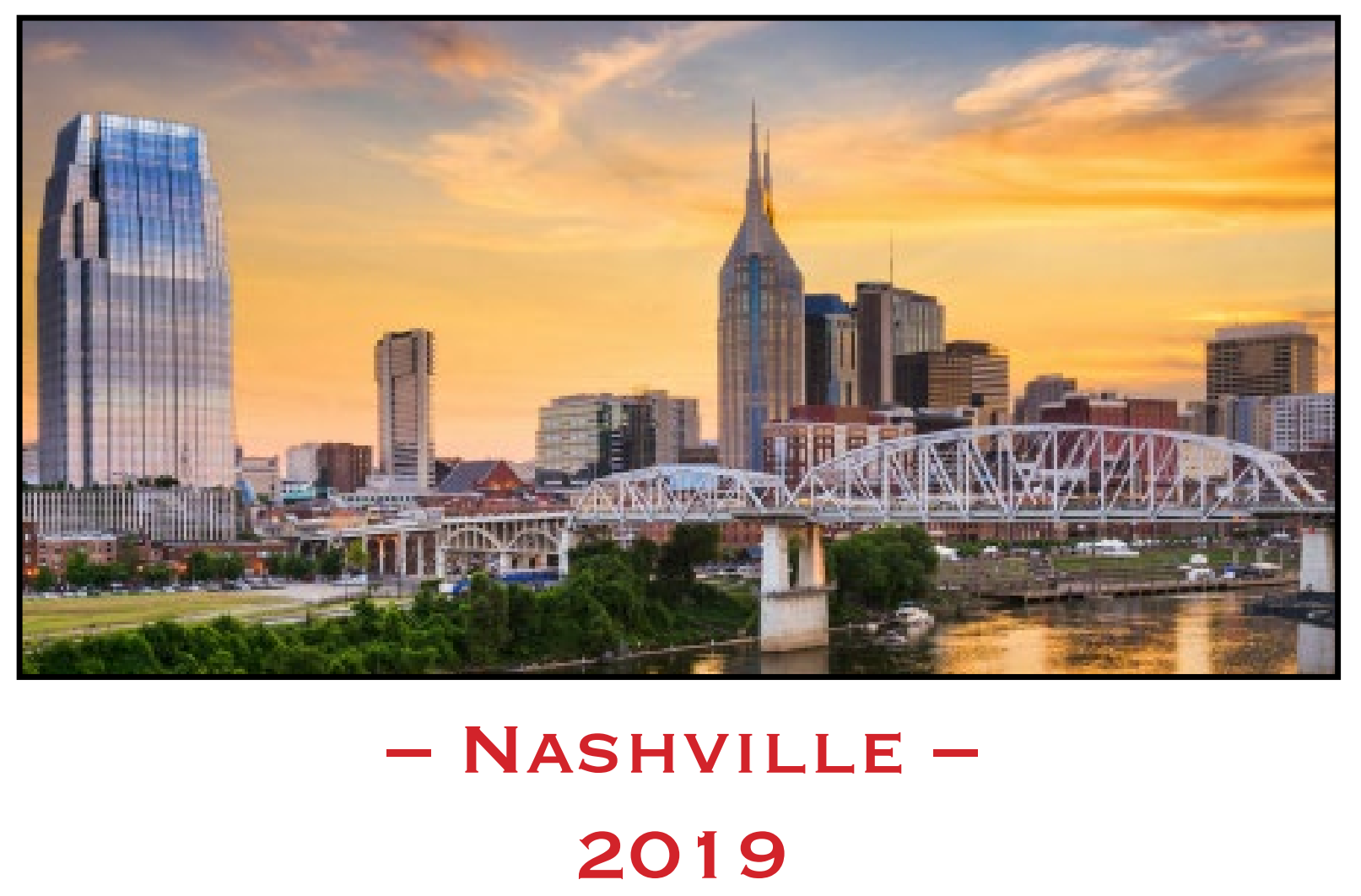

March 21 - 23, $2019 \cdot$ Belmont University - Nashville 